ISSN 1823-626X

Journal of Fundamental Sciences

available online at http://jfs.ibnusina.utm.my

\title{
Chemical constituents and antiviral study of Goniothalamus velutinus
}

\author{
Fasihuddin Badruddin Ahmad*, Nur Khairun Nisa’ Mohd Sallehuddin and Zaini Assim \\ Department of Chemistry, Faculty of Resource Science and Technology, Universiti Malaysia Sarawak, 94300 Kota Samarahan, Sarawak.
}

Received 12 March 2010, Revised 4 April 2010, Accepted 13 April 2010, Available online 25 May 2010

\begin{abstract}
Phytochemical study on the stem barks of Goniothalamus velutinus resulted in the isolation of three compounds identified as goniothalamin (1), pinocembrine (2) and naringenin (3). Their structures were elucidated using various spectroscopic methods especially Fourier Transform Infrared (FTIR), Nuclear Magnetic Resonance (NMR) and gas chromatography-mass spectrometry (GC-MS). Goniothalamin (1) has been isolated from several Goniothalamus spp. but no report on the isolation of (1) from Goniothalamus velutinus. Antiviral properties of (1) against Measles virus showed weak activity compared to positive control, ribavirin.
\end{abstract}

| Goniothalamus velutinus | goniothalamin | pinocembrine | naringenin | antiviral |

\section{INTRODUCTION}

Goniothalamus is a genus of shrubs and aromatic trees belongs to the Annonaceae family with approximately 160 species distributed in South Eastern Asia and throughout Malaysia [1]. The stem bark is aromatic and grows up to about $2 \mathrm{~m}$ tall. This genus is widely used in traditional medicines by natives especially for abortion and post partum treatment. For example, decoctions of $G$. macrophyllus and G. scortechnii are used as a post partum protective remedy while the roots of $G$. tapis and $G$. giganteus are used for abortion during early month of pregnancy [2]. Phytochemical investigations of Goniothalamus spp. resulted in the isolation of acetogenins, styryl lactones and alkaloids with significant cytotoxic, insecticidal and antimicrobial activities [3]. G. velutinus, locally known as 'Kayu Hujan Panas' is one of the interesting endemic Goniothalamus spp. of Borneo. It is a small tree up to $3 \mathrm{~m}$ tall and $3 \mathrm{~cm}$ diameter. The specific medicinal uses are not clearly described but the natives of Sabah and Sarawak use the roots decoction for the treatment of headaches and food poisoning [4,5]. The strong smell from the stem bark used as a mosquito repellent [5]. Previous study on G. velutinus resulted in the isolation of two alkaloids which have been identified as phenanthrene lactam and aristolactam BII [4]. This paper will discuss the isolation of goniothalamin (1), pinocembrine (2) and naringenin (3) from the stem barks of G. velutinus.

Corresponding author at: Department of Chemistry, Faculty of Resource Science and Technology, Universiti Malaysia Sarawak, 94300 Kota Samarahan, Sarawak. E-mail addresses: bfasih@frst.unimas.my (Fasihuddin Badruddin Ahmad)

\section{EXPERIMENTAL}

\subsection{General.}

IR: $\mathrm{KBr}$ discs and was recorded using Shimadzu FTIR-8201 PC spectrometer. ${ }^{1} \mathrm{H}$ and ${ }^{13} \mathrm{C}$-NMR were recorded on a JEOL $500 \mathrm{MHz}$ NMR spectrometer: $500 \mathrm{MHz}$ for ${ }^{1} \mathrm{H}$ and $125 \mathrm{MHz}$ for ${ }^{13} \mathrm{C}$, with $\mathrm{CDCl}_{3}$ and acetone- $\mathrm{D}_{6}$ as solvents. Melting point was measured using STUART smp 3 instrument and was uncorrected. GC-MS analysis was performed using Hewlett Packard 6890 instrument.

\subsection{Plant material.}

Goniothalamus velutinus Airy-Shaw was collected from Limbang, Sarawak. All parts were divided into leaves, stem barks and roots, air dried and ground to fine powder. A voucher specimen (HUMS0061) was deposited at Universiti Malaysia Sarawak Herbarium.

\subsection{Extraction and isolation.}

Stem barks powder $(2.0 \mathrm{~kg})$ was extracted with hexane followed by dichloromethane $\left(\mathrm{CH}_{2} \mathrm{Cl}_{2}\right)$, chloroform $\left(\mathrm{CHCl}_{3}\right)$, ethyl acetate (EtOAc) and methanol each $(\mathrm{MeOH})$ for three days at room temperature. Each extract was evaporated to dryness to give $4.70 \mathrm{~g}(0.24 \%), 33.70 \mathrm{~g}$ $(1.67 \%), 12.10 \mathrm{~g}(0.60 \%), 6.40 \mathrm{~g}(0.32 \%)$ and $16.30 \mathrm{~g}$ $(0.82 \%)$ of hexane, $\mathrm{CH}_{2} \mathrm{Cl}_{2}, \mathrm{CHCl}_{3}$, EtOAc and $\mathrm{MeOH}$, crude extract respectively. The $\mathrm{CH}_{2} \mathrm{Cl}_{2}$ extract afforded $0.70 \mathrm{~g}$ of white precipitate which was labelled as NKNGVG1. NKNGV-G1 was dissolved in $\mathrm{CH}_{2} \mathrm{Cl}_{2}$ followed by 
addition of hexane drop wise to form cloudy solution and left at room temperature. The precipitates were filtered and dried at room temperature. This method was repeated several times to give $91 \mathrm{mg}$ of compound (1) with $\mathrm{R}_{\mathrm{f}} 0.6$ (hexane: $\left.\mathrm{CH}_{2} \mathrm{Cl}_{2} ; 1: 4\right)$. In order to form a perfect crystal shape for X-ray crystallography analysis, $10 \mathrm{mg}$ of compound (1) was redissolved in $20 \mathrm{~mL}$ of $\mathrm{CHCl}_{3}$ and allowed to evaporate slowly in a test tube.

The MeOH crude extract of the stem barks of $G$. velutinus afforded $30 \mathrm{mg}$ precipitate each and labelled as $\mathrm{S} 1$ and S2. Exactly $25 \mathrm{mg}$ of S1 was further purified using prep. TLC in $\mathrm{CHCl}_{3}$ :acetone $(4: 1)$ to give $15 \mathrm{mg}$ of compound (2). Using prep. TLC in similar solvent system, $25 \mathrm{mg}$ of $\mathrm{S} 2$ afforded $12 \mathrm{mg}$ of compound (3). All compounds were identified as goniothalamin (1), pinocembrine (2) and naringenin (3) based on spectroscopic data and comparison with published information.

\subsection{Goniothalamin (1):}

Colourless needle crystals; m.p. 83-84 ${ }^{\circ} \mathrm{C}$; (lit [7] 80$82^{\circ} \mathrm{C}$ ); IR $v_{\max } \mathrm{cm}^{-1} 1720,1703,1388$ and 1249; MS m/z (\%): $200\left[\mathrm{M}^{+}, \mathrm{C}_{13} \mathrm{H}_{12} \mathrm{O}_{2}\right](82 \%), 172\left[\mathrm{M}^{+}\right.$- CO] (29\%), 131 $\left[\mathrm{C}_{9} \mathrm{H}_{7} \mathrm{O}\right]^{+}(26 \%), 115\left[\mathrm{C}_{9} \mathrm{H}_{7}\right]^{+}(24 \%), 104\left[\mathrm{C}_{8} \mathrm{H}_{8}\right]^{+}(100 \%)$, $91\left[\mathrm{C}_{7} \mathrm{H}_{7}\right]^{+}(50 \%), 68\left[\mathrm{C}_{4} \mathrm{H}_{4} \mathrm{O}\right]^{+}(95 \%) ;{ }^{1} \mathrm{H}$ NMR $(500 \mathrm{MHz})$ $\left(\mathrm{CDCl}_{3}\right)$ ppm: $\delta 7.31(\mathrm{~m}, 5 \mathrm{H}$, aromatic protons), $\delta 6.92(\mathrm{dt}$, $9.8 \mathrm{~Hz}, 4.3 \mathrm{~Hz}, 1 \mathrm{H}, \mathrm{H}-3), \delta 6.73(\mathrm{~d}, 16.0 \mathrm{~Hz}, 1 \mathrm{H}, \mathrm{H}-8), \delta$ 6.29 (dd, 16.0 Hz, 6.3 Hz, 1H, H-7), $\delta 6.09$ (dt, $9.8 \mathrm{~Hz}, 1.6$ $\mathrm{Hz}, 1 \mathrm{H}, \mathrm{H}-4), \delta 5.11$ (m, 1H, H-6), $\delta 2.57$ (m, 2H, H-5); ${ }^{13} \mathrm{C}$ NMR (125 MHz) $\left(\mathrm{CDCl}_{3}\right): \delta 29.9(\mathrm{C}-5), \delta 77.9(\mathrm{C}-6), \delta$ 121.7 (C-3), $\delta 125.6$ (C-7), $\delta 126.7$ (C-10 \& C-14), $\delta 128.3$ (C-12), $\delta 128.7$ (C-11 \& C-13), $\delta 133.1$ (C-8), $\delta 135.8$ (C9), $\delta 144.6(\mathrm{C}-4), \delta 163.8(\mathrm{C}-2)$.

\subsection{Pinocembrine (2):}

Yellowish amorphous solid; m.p 196.9-197.7 ${ }^{\circ} \mathrm{C}$; (lit [8] 191-192 $\left.{ }^{\circ} \mathrm{C}\right)$; IR $v_{\max } \mathrm{cm}^{-1} 3090,2890,1631,1604,1487$ and 1169; MS m/z (\%): $256\left[\mathrm{M}^{+}, \mathrm{C}_{15} \mathrm{H}_{12} \mathrm{O}_{4}\right](91 \%), 238$ (10.5\%), 179 (98.2\%), $152(100 \%), 124(73.7 \%)$ and 91 (8.7\%); ${ }^{1} \mathrm{H}$ NMR $(500 \mathrm{MHz})\left(\mathrm{CDCl}_{3}\right)$ ppm: $\delta 5.43(\mathrm{dd}, 3.2$ $\mathrm{Hz}, 12.8 \mathrm{~Hz}, 1 \mathrm{H}, \mathrm{H}-2), \delta 3.11$ (dd, $12.8 \mathrm{~Hz}, 17.2 \mathrm{~Hz}, 1 \mathrm{H}$, $\mathrm{H \alpha}-3$ ), $\delta 2.84$ (dd, $3.2 \mathrm{~Hz}, 17.2 \mathrm{~Hz}, 1 \mathrm{H}, \mathrm{H} \beta-3), \delta 6.00$ (s, $1 \mathrm{H}, \mathrm{H}-6), \delta 6.00(\mathrm{~s}, 1 \mathrm{H}, \mathrm{H}-8), \delta$ 7.37-7.44 (m, 5H, aromatic protons), $\delta 12.02(\mathrm{~s}, 1 \mathrm{H}, \mathrm{OH}) ;{ }^{13} \mathrm{C}$ NMR $(125 \mathrm{MHz})$ $\left(\mathrm{CDCl}_{3}\right)$ ppm: $\delta 79.20(\mathrm{C}-2), \delta 43.20(\mathrm{C}-3), \delta 195.80(\mathrm{C}-4)$, $\delta 163.18(\mathrm{C}-5), \delta 96.76(\mathrm{C}-6), \delta 164.55(\mathrm{C}-7), \delta 95.49(\mathrm{C}-$ 8), $\delta 164.36$ (C-9), $\delta 103.24$ (C-10), $\delta 138.28$ (C-1'), $\delta$ 128.88 (C-4'), $\delta 126.13$ (C-2' \& C-6') and $\delta 128.91$ (C-3' \& C-5').

\subsection{Naringenin (3):}

Yellowish amorphous solid; m.p. 250-251 ${ }^{\circ} \mathrm{C}$; (lit [9] 249-252 ${ }^{\circ} \mathrm{C}$ ); IR $v_{\max } \mathrm{cm}^{-1} 3124,2832,1630,1603,1463$ and 1158; $\mathrm{MS} \mathrm{m} / \mathrm{z}(\%): 272\left[\mathrm{M}^{+}, \mathrm{C}_{15} \mathrm{H}_{12} \mathrm{O}_{5}\right](60 \%), 179$ (26.7\%), 166 (27.7\%), 153 (100\%), 120 (61.4\%), 107
(17.8\%) and 91 (23.8\%); ${ }^{1} \mathrm{H}$ NMR $(500 \mathrm{MHz})$ (acetone- $\mathrm{D}_{6}$ ) ppm: $\delta 5.45$ (d, $13.0 \mathrm{~Hz}, 1 \mathrm{H}, \mathrm{H}-2), \delta 2.73(\mathrm{~d}, 17.0 \mathrm{~Hz}, 1 \mathrm{H}$, $\mathrm{H} \alpha-3$ ), $\delta 3.17$ (dd, $17.0 \mathrm{~Hz}, 13.0 \mathrm{~Hz}, 1 \mathrm{H}, \mathrm{H} \beta-3), \delta 5.96$ (s, $1 \mathrm{H}), \delta 5.96(\mathrm{~s}, 1 \mathrm{H}, \mathrm{H}-6), \delta 7.40(\mathrm{~d}, 7.6 \mathrm{~Hz}, 1 \mathrm{H}, \mathrm{H}-2$ '), $\delta$ 6.90 (d, 7.6 Hz, 1H, H-3'), $\delta 6.90$ (d, 7.6 Hz, 1H, H-5'), $\delta$ 7.40 (d, 7.6 Hz, 1H, H-6'), $\delta 12.18(\mathrm{~s}, 1 \mathrm{H}, \mathrm{OH}) ;{ }^{13} \mathrm{C} \mathrm{NMR}$ (125 MHz) (acetone-D $)_{6}$ ppm: $\delta 79.9(\mathrm{C}-2), \delta 43.4(\mathrm{C}-3), \delta$ 197.1 (C-4), $\delta 165.3$ (C-5), $\delta 95.9$ (C-6), $\delta 167.7$ (C-7), $\delta$ 96.8 (C-8), $\delta 164.3$ (C-9), $\delta 103.0$ (C-10), $\delta 128.9$ (C-1'), $\delta$ 130.7 (C-2' \& C-6'), $\delta 116.1$ (C-3' \& C-5'), $\delta 158.7$ (C-4').

\subsection{Antiviral assay.}

Vero cells were seeded onto 96 wells microtiter plate with a concentration of $1.0 \times 10^{5}$ cells per $\mathrm{mL}$ and a volume of $100 \mu \mathrm{L}$ per well. Plate was then incubated at $37^{\circ} \mathrm{C}$ with $5 \% \mathrm{CO}_{2}$ overnight to obtain confluent monolayer cells. After that, the growth medium in each well was discarded and cells were washed with sterile phosphate buffered saline (PBS). In order to determine the mode of antiviral action, cells and virus were incubated with compound (1) at different stages during the viral infection cycle.

\section{a) Pre-infection protocol}

The diluted compound (1) was added to cells and incubated at $37^{\circ} \mathrm{C}$ in $\mathrm{CO}_{2}$ incubator for 24 hours. After this incubation, the compound was aspirated and replaced with $10 \mu \mathrm{L}$ measles virus and growth medium before incubated again for 72 hours.

\section{b) Virucidal protocol}

Compound dilutions $(200 \mu \mathrm{L})$ were prepared in 96 wells microtiter plate. Measles virus $(10 \mu \mathrm{L})$ was added to each well (except for control) and the mixtures were left for an hour at $37^{\circ} \mathrm{C}$. After that, the virus-compound mixtures were added to cells and plate was incubated at $37^{\circ} \mathrm{C}$ for 72 hours in $\mathrm{CO}_{2}$ incubator [6].

\section{c) Post-infection protocol}

Cells were inoculated with measles virus $(10 \mu \mathrm{L})$ first, followed by one hour incubation at $37^{\circ} \mathrm{C}$ in $\mathrm{CO}_{2}$ incubator to allow the virus to absorb and penetrate the cells. Then, $200 \mu \mathrm{L}$ diluted compound was added to the infected cells and plate was incubated at $37^{\circ} \mathrm{C}$ for 72 hours in $\mathrm{CO}_{2}$ incubator.

There were four controls involved in this test; (i) cells inoculated with virus only, (ii) cells added with compound only, (iii) cells only and (iv) Dulbecco's modified Eagle's medium (DMEM) only. Ribavirin at concentration of $0.1 \quad \mathrm{LC}_{50}$ and $0.01 \mathrm{LC}_{50}$ was used as positive control. After 72 hours, plate was processed using Eosin B assay and ELISA reader at 490nm. 


\section{RESULTS \& DISCUSSION}

Three pure compounds identified as goniothalamin (1), two known flavonoids namely pinocembrine (2) and naringenin (3) have been isolated from $G$. velutinus.

Compound (1) was isolated from the dichloromethane extract of the stem bark of $G$. velutinus. It is known as embryotoxic styryl lactone which was previously isolated from several Goniothalamus spp. such as G. macrophyllus, G. clemensii, G. andersonii and $G$. malayanus ${ }^{[7,10-12]}$ but this is the first report of the isolation of (1) from $G$. velutinus. The ${ }^{1} \mathrm{H}$ NMR spectrum of (1) revealed the signal at $\delta 6.92(\mathrm{dt}, 9.8 \mathrm{~Hz}, 4.3 \mathrm{~Hz})$ for $\mathrm{H}-3$ and $\delta 6.09(\mathrm{dt}, 9.8 \mathrm{~Hz}, 1.6 \mathrm{~Hz})$ for $\mathrm{H}-4$ as olefinic proton of lactone skeleton. Two proton signal observed at $\delta 2.57(\mathrm{~m}$, $2 \mathrm{H}$ ) for proton at $\mathrm{H}-5$ appeared as multiplet. Another two olefinic protons appeared at $\delta 6.29(\mathrm{dd}, 16.0 \mathrm{~Hz}, 6.3 \mathrm{~Hz})$ and $\delta 6.73(\mathrm{~d}, 16.0 \mathrm{~Hz})$ which were ascribed to protons $\mathrm{H}-7$ and $\mathrm{H}-8$ respectively. The signal which appeared at $\delta 5.11$ $(\mathrm{m}, 1 \mathrm{H})$ assignable to the proton $\mathrm{H}-6$. The signal at $\delta 7.31$ $(\mathrm{m}, 5 \mathrm{H})$ was ascribed to proton of phenyl group in (1). The ${ }^{13} \mathrm{C}$ NMR spectrum gave signals at $\delta 126.7$ (C-10 and C14), $\delta 128.3$ (C-12), $\delta 128.7$ (C-11 and C-13) and $\delta 135.8$ (C-9). These signals indicated the presence of mono substituted phenyl carbons which also supported by ${ }^{1} \mathrm{H}$ NMR which gave signal at $7.31(\mathrm{~m}, 5 \mathrm{H})$ assignable to the proton of an aromatic ring. The signal at $\delta 163.8$ was ascribed to $\mathrm{C}-2$ indicated the presence of carbonyl group which also proved previously by IR spectrum at absorption band of $1719 \mathrm{~cm}^{-1}$. The spectral data, melting point and physical properties of (1) were identical with goniothalamin that has been isolated from G. macrophyllus [7] thus (1) has been identified as goniothalamin. Previous studies reported that, goniothalamin was found to possess anticancer properties against colon cancer cell line (LS-174T and HT29) and breast cancer cell line (MCF-7), lung carcinoma (COR-L23 and NCI.460), kidney tumor cell line (786-0) with $\mathrm{IC}_{50}$ values of $3.41 \mu \mathrm{g} / \mathrm{mL}, 12.62 \mu \mathrm{g} / \mathrm{mL}$ and 23.33 $\mu \mathrm{g} / \mathrm{mL}$ and $4 \mathrm{nM}$ respectively. It also showed cytotoxicity and genotoxicity against human HL-60 promyelocytic leukemia cells and CEM-SS T-lymphoblastic cells with $\mathrm{IC}_{50}$ values of $4.5 \mu \mathrm{g} / \mathrm{mL}$ and $2.4 \mu \mathrm{g} / \mathrm{mL}$ respectively $[7,13,14]$.<smiles>O=C1C=CCC(/C=C/c2ccccc2)O1</smiles>

1<smiles>O=C1CC(c2ccccc2)Oc2cc(O)cc(O)c21</smiles><smiles>O=C1CC(c2ccc(O)cc2)Oc2cc([125I])cc(O)c21</smiles>

3

Compound (2) was isolated as yellowish amorphous solids, melting point $196.9-197.7^{\circ} \mathrm{C}$ and gave IR absorptions at 3090, 2890, 1631, 1604, 1487 and $1169 \mathrm{~cm}^{-1}$ indicating the presence of hydroxyl, carbonyl and phenyl group. The gas chromatogram showed a molecular ion peak at $\mathrm{m} / \mathrm{z} 256$ which corresponding to a molecular formula of $\mathrm{C}_{15} \mathrm{H}_{12} \mathrm{O}_{4}$. The ${ }^{1} \mathrm{H}$ NMR spectrum for (2) showed some similarities when compared to compound (3). Two signals were observed at H-3 and the proton of hydroxyl group appeared at $\delta 12.02$ for both compounds. Two signals appeared as doublet of doublet at $\delta 3.11(\mathrm{~J}=12.8,17.2 \mathrm{~Hz})$ and $\delta 2.84(\mathrm{~J}=3.2,17.2 \mathrm{~Hz})$ were attributed to proton at $\mathrm{H}-$ $3 \alpha$ and $H-3 \beta$ respectively. The multiplet signal within the range of $\delta$ 7.37-7.44 was assigned to aromatic protons. From the ${ }^{13} \mathrm{C}$ NMR spectrum, carbonyl group was observed by the peak appeared at $\delta 195.80$ while the signals appeared at $\delta 128.88$ and $\delta 138.28$ were assigned to aromatic carbons at $\mathrm{C}-4$ ' and $\mathrm{C}-1$ ' respectively. Two aromatic carbons which are C-2' and C-6' were in the similar environment observed from the peak appeared at $\delta$ 126.13 while the signal at $\delta 128.91$ was assigned to aromatic carbons at position C-3' and C-5'.

Compound (3) was isolated as yellow amorphous solid, melting point $250-251^{\circ} \mathrm{C}$ and gave a molecular ion peak at $\mathrm{m} / \mathrm{z} 272$ which corresponding to a molecular formula $\mathrm{C}_{15} \mathrm{H}_{12} \mathrm{O}_{5}$. A strong absorption at $1630 \mathrm{~cm}^{-1}$ was ascribed to carbonyl group due to conjugation with the aromatic system. The ${ }^{1} \mathrm{H}$ NMR spectrum for compound (3) revealed a singlet signal at $\delta 12.18$ indicated the proton of hydroxyl group. The proton at position $\mathrm{H}-3$ resonated as two signals at $\delta 2.73(\mathrm{~d}, 17.0 \mathrm{~Hz})$ and $\delta 3.17(\mathrm{dd}, 17.0 \mathrm{~Hz}$, $13.0 \mathrm{~Hz}$ ) assignable to proton $\mathrm{H} \alpha-3$ and $\mathrm{H} \beta-3$ respectively. The doublet peaks appeared at $\delta 6.90$ was attributed to aromatic protons at position $\mathrm{H}-3$ ' and $\mathrm{H}-5$ ' while the other doublet signal appeared at $\delta 7.40$ was assigned to aromatic proton at $\mathrm{H}-2$ ' and $\mathrm{H}-6$ '. The ${ }^{13} \mathrm{C}$ NMR spectrum showed a signal at $\delta 197.1$ indicated the presence of carbonyl group at position C-4. Two signals observed at $\delta 165.3$ and $\delta 167.7$ were assigned to $\mathrm{C}-5$ and $\mathrm{C}-7$. The signal at $\delta 158.7$ was attributed to aromatic carbon, C-4'. Two aromatic carbons were observed at $\delta 116.1$ for $\mathrm{C}-3^{\prime}$ ' and C-5'. The signal appeared at $\delta 130.7$ were assigned to C-2' and C-6'.

Comparing the chemical shift of C-4' in (2) and (3), showed the value of C-4' in (3) was in the lower field due to the presence of hydroxyl substituent at C-4' of (3). Based on the ${ }^{1} \mathrm{H}$ and ${ }^{13} \mathrm{C}$ NMR spectra, (2) and (3) were elucidated as pinocembrine and naringenin, respectively. The melting point and the spectroscopic data of these compounds were in good agreement with the published data $[8,9,15,16]$. 
Pinocembrine (2) has been previously isolated from Chilean propolis, Lippa gravolen, Galenia africana, Pinus strobes, $G$. scortechnii and found to posses antifungal and antioxidant properties [8,16,17]. Naringenin (3) has been isolated from Amygdalus lycioides var. horrida and Commiphora wightii and reported to have antioxidant properties [15,18,19].

In this study, antiviral properties of compound (1) was tested against Measles virus and showed weak activity compared to positive control, ribavirin. Pretreatment of cells with (1) before addition of Measles virus caused a significant reduction of infectivity. Measles virus titer was reduced by more than $98 \%$ at a concentration of $0.1 \mathrm{LC}_{50}$. However, no significant effect on viral replication was detected when ribavirin was used for pretreatment of viruses or when added after the adsorption phase. The antiviral activity of (1) is summarized in Table 1.

Table 1. The effect of compound 1 against Measles virus compared to ribaxinin

\begin{tabular}{cccc}
\hline Concentration of pure & \multicolumn{3}{c}{ Viral inhibition rate (\%) } \\
\cline { 2 - 4 } compound $(\mu \mathrm{g} / \mathrm{mL})$ & Pre-infection & Virucidal & Post-infection \\
\hline $0.1 \mathrm{LC}_{50}$ & 98.41 & 31.41 & 17.3 \\
$0.01 \mathrm{LC}_{50}$ & 22.4 & - & - \\
Ribavirin (control) & & & 23.79 \\
$0.1 \mathrm{LC}_{50}$ & 100 & 55.08 & 32.28 \\
$0.01 \mathrm{LC}_{50}$ & 100 & 50.25 & \\
\hline
\end{tabular}

\section{CONCLUSION}

Three compounds identified as goniothalamin (1), pinocembrine (2) and naringenin (3) have been isolated from the stem barks of $G$. velutinus. Goniothalamin (1) inhibited $98 \%$ of viral replication before the addition of Measles virus at concentration of $0.1 \mathrm{LC}_{50}$ however no significant activity was observed after the addition and adsorption phase of the virus to the cell.

\section{ACKNOWLEDGEMENT}

The authors wish to acknowledge Universiti Malaysia Sarawak (UNIMAS) for financial support through grant number ZRC/02/2007(02), FRGS/06 (01)/ 643/2007 (08) and 01(S26)/676/2008(09) and research facilities. We thank Mdm Norhayati Bujang for her assistance in optimizing NMR experiments and Universiti Kebangsaan Malaysia (UKM) for GC-MS data.

\section{REFERENCES}

[1] Goh, S.H., EE, G.C.L. and Chuah, C.H., 1995a. Natural Product Letters 5: 255-259.

[2] Wiart, C., 2007. Evidence-based Complementary and Alternative Medicine 4: 299-311.

[3] Seidel, V., Bailleul, F. and Waterman, P.G., 2000. Phytochemistry 55: 439-446.

[4] Omar, S., Chee, L.C., Ahmad, F., Ni, J.X., Jaber, H., Huang, J. and Nakatsu, T., 1992. Phytochemistry 31: $4395-4397$.

[5] Latif, A., Ibrahim, A.Z. and Hanum, F., 1998. Retrieved from ASEAN Review of Biodiversity and Environmental Conservation (ARBEC), www.arbec.com.my. Kuala Lumpur. pp 1-20.

[6] Roner, M.R., Sprayberry, J., Spinks, M. and Dhanji, S., 2007. Journal of General Virology 88: 275-285.

[7] Wattanapiromsakul, C., Wangsintaweekul, B., Sangprapan, P., Itharat, A. and Keawpradub, N., 2005. Journal of Science Technology 27: 479-487.

[8] Aryanti, A., Zuriati, Z., Fasihuddin, B.A., Mat Salleh, K. and Din, Laily, D. 2009. Sains Malaysiana 38: 365-369.

[9] Almahy, H.A., Rahmani, M., Sukari, M.A. and Ali, A.M., 2003. Pertanika Journal of Science and Technology 11: 73-81.

[10] Jewers, K., Davis, J.B., Dougan, J. and Manchanda, A.H., 1972.Phytochemistry 11: 2025-2030.

[11] Fasihuddin, B.A. and Din, L.B., 2001. Isolation Journal of Tropical Medicinal Plants 2: 23-27.

[12] Sam, T.W., Sew-Yeu, C., Matsjeh, S., Gan, E.K., Razak, D. and Mohamed, A.L., 1987. Tetrahedron Letters 28: $2541-2544$.

[13] Rajab, N.F., Hamid, Z.A., Hassan, H., Ali, A.M., Din, L. and Hussain, S.H.I., 2005. Environmental Mutagen Research 27: 161-164.

[14] Fatima, A., Kohn, L.K., Carvalho, J.E. and Ronaldo, A.P., 2006. Bioorganic and Medicinal Chemistry 14: 622-631.

[15] Fatope, M.O., Al-Burtomani, S.K.S., Ochei, J.O., Abdulnour, A.O., Al-Kindy, S.M.Z and Takeda, Y., 2003. Phytochemistry 62: $1251-1255$.

[16] Astudillo, L., Avila, F., Morrison, R., Gutierrez, M., Bastida, J., Codina, C., Hirschman, G.S., 2000. Boletin Sociedad Chilena Quimica 45: 1-6.

[17] Brown, M.P., Henderson, D.E. and Hunt, C., 2006. Electronic Journal of Environmental, Agricultural and Food Chemistry 5: $1265-1277$.

[18] Subramaniam, V., Adenan, M.I., Ahamd, A.R. and Sahdan, R., 2003, Malaysia Journal Nutrition 9: 41-51.

[19] Babaei, H., Sadeghpour, O., Nahar, L., Delazar, A., Nazemiyeh, H., Mansouri, M.R., Poursaeid, N., Asnaashari, S., Moghadam, S.B. and Sarker, S.D., 2008. Turkish Journal of Biology 32: 203-208. 